\author{
M.Yu. Ishmuratova*, D.S. Baigarayev, S.U. Tleukenova, \\ E.A. Gavrilkova, A.K. Ramasanov, A.G. Zhumina \\ Karagandy University of the name of academician E.A. Buketov, Kazakhstan \\ *Corresponding author: margarita.ishmur @ mail.ru
}

\title{
Development of cryopreservation methods of seed of Nepeta cataria
}

\begin{abstract}
This article presents the summarized data on cryopreservation of seeds of the medical plant Nepeta cataria. Cryopreservation is a highly promising method for saving of seed materials, allowing to organize long-term storage without viability loss. The purpose of present work is to optimize conditions of cryopreservation of seed materials of Nepeta cataria. Assessment of seed survival rate in the storage showed a linear decrease in seed viability and energy of germination. After 30 months of storage at the low positive temperature $\left(+5^{\circ} \mathrm{C}\right)$ in paper pack seed rate decreased to $12.0 \%$ and energy of germination to $11.2 \%$; after 4 years of storage seeds lost viability. During conduction of research the type of container, condition of thawing, optimal moisture of seeds and cryoprotectants are optimized. The optimal container for cryopreservation in liquid nitrogen was plastic cryo tubes; defrosting at room temperature. The best seed rate is found at moisture $3 \%$; the best cryoprotectant was glucose, the optimal concentration was $15 \%$. The result of the research is used for creation of the long-term storage medicinal cultures' seed bank in the liquid nitrogen.
\end{abstract}

Keywords: Nepeta cataria, medicinal plant, seed materials, germination, liquid nitrogen, cryo protectants, cryopreservation.

\section{Introduction}

Republic of Kazakhstan has the great resources of wild and cultivated medicinal plants [1], the most of which are used for development of new medicine prepared on their base [2]. So, cultivation of the medicinal plants is limited by the deficit of seed production and absent seed banks. Research on the development of methods for storing seed materials is relevant and has potential for practical application. One of the modern methods is cryopreservation in liquid nitrogen [3-5], which allows stopping physiological processes and ensuring long-term storage at extra low temperature. Early conducted research shows the need for individual selection of conditions for cryo freezing for each taxon [6-8].

The perspective object is Nepeta cataria L. (Lamiaceae family), above-ground organs of which are used in folk and official medicine as antispasmodic, tonic, stimulating remedies [9]. The infusions are used for treatment of gastrointestinal and respiratory diseases, gallbladder and bile pathways, against hysteria and depression conditions [10, 11]. Infusion of raw material of Nepeta cataria reduces the temperature, has sedative, antimicrobial and anti-oxidant effect [12-17].

The purpose of present study is to develop of the conditions of cryopreservation of Nepeta cataria's seed material.

\section{Materials and methods}

The collection of seeds of Nepeta cataria is made from nature on Spassky hills (Bukhar Zhirau district of the Karagandy region) in 2018. Species affiliation is determined by the Flora of Kazakhstan [18]. A sample of the plant is stored in the herbarium fund of the Faculty of Biology and Geography of E.A. Buketov Karaganda University.

The experiments are conducted on the base of Research Park of Biotechnology and Eco-Monitoring of E.A. Buketov Karaganda University. For experiments all seeds are cleaned, dried to a humidity of 3, 7 and $12 \%$; and divided into batches of 100 pieces (Fig. 1). Freezing of seeds was carried out in 2 types of containers (foil package and plastic cryo tubes) in Dewar vessels CDC 20 (CryoMash) according to methodological guidelines [19-21]. The moisture content in seed is obtained as mean percentage between fresh and fried weight (3 independent determinations). 


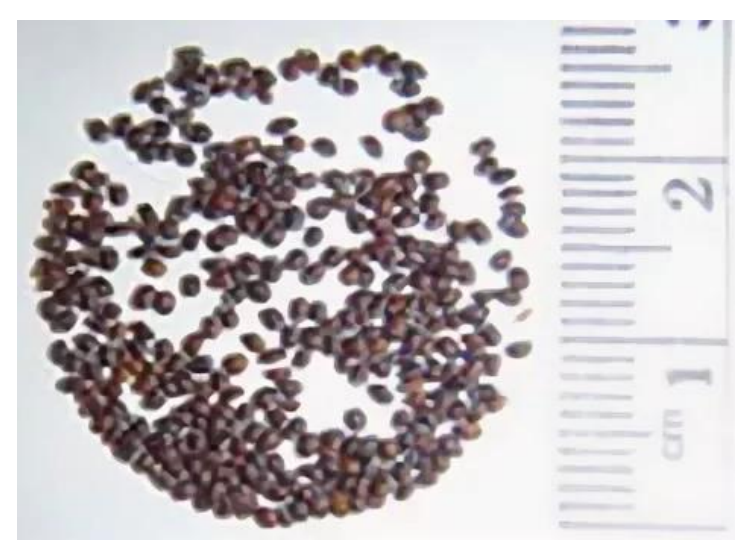

Figure 1. Seeds of Nepeta cataria

Defrosting after freezing is carried out in 2 variants: a) rapid defrosting in water bath $\left(40{ }^{\circ} \mathrm{C}\right)$ for $10-15$ minutes; b) slow defrosting at room temperature $\left(22-23^{\circ} \mathrm{C}\right)$ for one hour. Seeds stored in the refrigerator $\left(+5^{\circ} \mathrm{C}\right)$ for 30 months were used as control variant.

In second series of experiments different cryo protectors were used: sucrose - 10 and $15 \%$; glucose 10 and $15 \%$; glycerin -20 and $40 \%$, propylene glycol -5 and $10 \%$. Seed materials are soaked in various solutions of cryoprotectants for 15 minutes, after which were placed in liquid nitrogen. As a control seeds frosted without cryoprotectants were used. After defrosting seeds are washed from cryoprotectors 3 times with distilled water.

To test the viability of all variants of seeds (experimental and control samples) they are sown in Petri dishes on two-layer filter paper moistened with distilled water [22]. The energy of germination (on $6^{\text {th }}$ day) and germination (on $15^{\text {th }}$ day) are noted.

The data is analyzed using Statistic program STATISTICA and package EXCEL-2010.

\section{Results and discussion}

The preliminary results of germination analysis show that the viability of Nepeta cataria's seeds quickly loses quality - from $46.2 \%$ for fresh to $12.0 \%$ after 30 months of traditional storage in refrigerator (Table 1).

T a b l e 1

Seed rate and energy of germination of Nepeta cataria after storage in low temperature $\left(+5^{\circ} \mathrm{C}\right)$

\begin{tabular}{|c|c|c|}
\hline Period of storage, month & Seed rate, $\%$ & Energy of germination, \% \\
\hline Fresh seeds & $46.2 \pm 1.5$ & $26.8 \pm 0.6$ \\
\hline 1 & $42.8 \pm 1.0$ & $23.9 \pm 0.4$ \\
\hline 3 & $38.6 \pm 1.5$ & $22.6 \pm 0.2$ \\
\hline 6 & $35.2 \pm 1.9$ & $24.3 \pm 0.2$ \\
\hline 9 & $27.1 \pm 1.2$ & $21.2 \pm 0.8$ \\
\hline 12 & $26.8 \pm 1.5$ & $20.7 \pm 0.8$ \\
\hline 15 & $20.3 \pm 1.1$ & $18.9 \pm 0.3$ \\
\hline 18 & $19.6 \pm 1.2$ & $17.4 \pm 0.1$ \\
\hline 21 & $18.9 \pm 1.3$ & $16.2 \pm 0.8$ \\
\hline 24 & $15.0 \pm 1.8$ & $15.1 \pm 0.6$ \\
\hline 27 & $14.1 \pm 1.6$ & $13.8 \pm 0.4$ \\
\hline 30 & $12.0 \pm 1.3$ & $11.2 \pm 0.8$ \\
\hline & & \\
\hline
\end{tabular}

The seed rate of Nepeta cataria after 1 month of storage decreased to $42.8 \%$; after 6 months to $35.2 \%$; after 12 months to $26.8 \%$; after 18 months to $19.6 \%$ (Fig. 2). Thus, optimal period of storage was 1-2 years. 


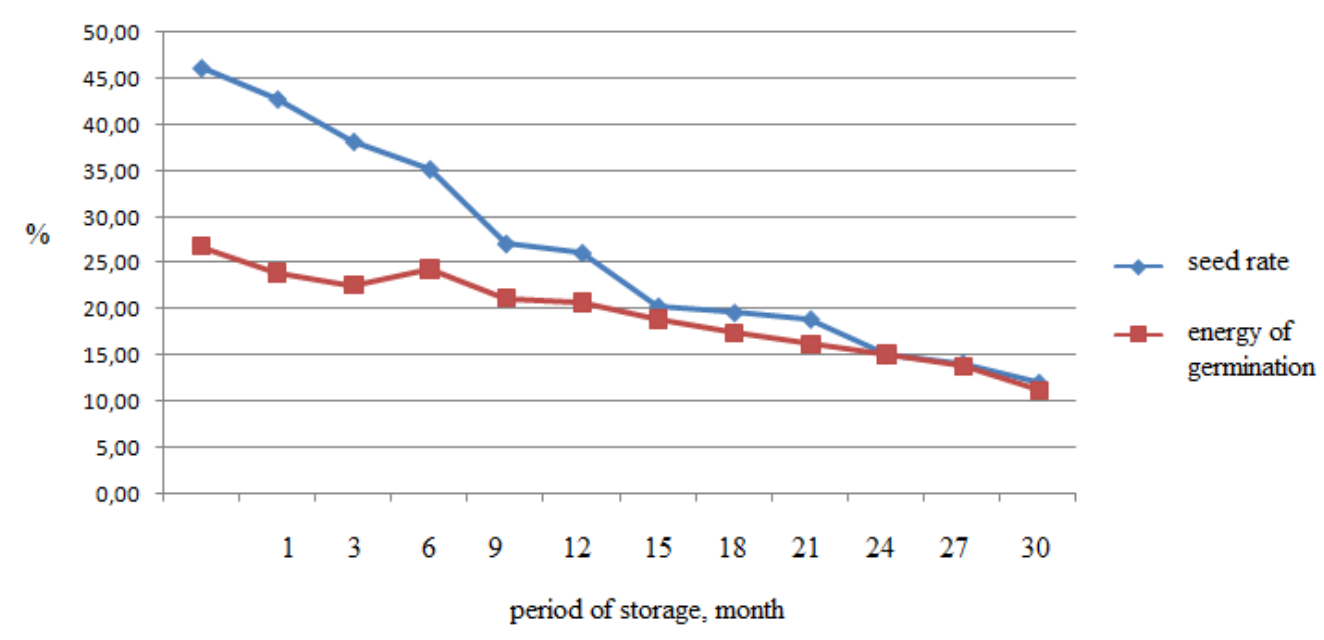

Figure 2. Seed rate and energy of germination of Nepeta cataria after 30 months of storage

On the next step the effects of kinds of package and methods of defrosting are studied. The results showed that after freezing, seed germination was higher than in the control variant (Table 2).

Table 2

\section{Seed rate and energy of germination of Nepeta cataria after cryopreservation in different containers and different methods of defrosting}

\begin{tabular}{|l|c|c|}
\hline \multicolumn{1}{|c|}{ Experimental variant } & Seed rate, $\%$ & Energy of germination, $\%$ \\
\hline Control (storage 2 years) & $26.8 \pm 1.5$ & $20.7 \pm 0.8$ \\
\hline $\begin{array}{l}\text { Cryopreservation, cryo tubes, } \\
\text { thawing at room temperature }\end{array}$ & $64.8 \pm 3.0$ & $52.0 \pm 1.6$ \\
\hline $\begin{array}{l}\text { Cryopreservation, foil pack, } \\
\text { thawing at room temperature }\end{array}$ & $58.7 \pm 2.9$ & $38.4 \pm 0.7$ \\
\hline $\begin{array}{l}\text { Cryopreservation, plastic cryo tubes, } \\
\text { thawing in water bath }\end{array}$ & $62.8 \pm 2.7$ & $42.9 \pm 0.7$ \\
\hline $\begin{array}{l}\text { Cryopreservation, foil pack, } \\
\text { thawing in water bath }\end{array}$ & $55.4 \pm 2.0$ & $42.3 \pm 0.5$ \\
\hline
\end{tabular}

The maximum seed rate and energy of germination are noted in the experimental variant of freezing in plastic cryo tube and defrosting in room temperature: $65.6 \%$ and $54.0 \%$, respectively.

The moisture of seeds is important in the organization of the storage system [19, 21]. We froze three versions of pot seeds with humidity $12 \% ; 7 \% ; 3 \%$. The results showed that maximum drying of seeds led to the best viability after thawing (Table 3 ).

Table 3

Indicators of seed viability of Nepeta cataria after cryopreservation depending on moisture content

\begin{tabular}{|c|c|c|}
\hline Moisture, $\%$ & Seed rate, $\%$ & Energy of germination, $\%$ \\
\hline 12 & $46.7 \pm 19.5$ & $27.8 \pm 5.6$ \\
\hline 7 & $54.2 \pm 19.7$ & $32.5 \pm 1.2$ \\
\hline 3 & $62.5 \pm 21.3$ & $47.8 \pm 2.5$ \\
\hline
\end{tabular}

Thus, $3 \%$ moisture of seed is optimal for cryopreservation.

One of the ways to increase viability of seeds is to use different cryoprotectants [19-21]. In our experiments three types of cryoprotectants with different concentration were used. The best variant is observed for $15 \%$ glucose concentration (Table 4). 
Seed rate and energy of germination of Nepeta cataria after using cryoprotectants

\begin{tabular}{|l|c|c|}
\hline \multicolumn{1}{|c|}{ Variant of experiment } & Seed rate, $\%$ & Energy of germination, $\%$ \\
\hline Control (without cryo protector) & $46.7 \pm 19.5$ & $27.8 \pm 5.6$ \\
\hline Glucose 10\% & $70.5 \pm 3.2$ & $48.9 \pm 1.5$ \\
\hline Glucose 15\% & $74.5 \pm 3.3$ & $58.9 \pm 1.6$ \\
\hline Sucrose 10\% & $65.6 \pm 3.7$ & $60.5 \pm 2.4$ \\
\hline Sucrose 15\% & $45.8 \pm 2.4$ & $24.4 \pm 1.7$ \\
\hline Glycerin 20\% & $42.8 \pm 3.0$ & $20.1 \pm 3.1$ \\
\hline Glycerin 40\% & $41.2 \pm 3.3$ & $20.5 \pm 3.3$ \\
\hline Propylene glycol 5\% & $61.3 \pm 3.7$ & $50.2 \pm 3.5$ \\
\hline Propylene glycol 10\% & $68.0 \pm 3.0$ & $65.8 \pm 1.8$ \\
\hline
\end{tabular}

Sucrose and propylene glycol gave higher results than in control variant. But both concentrations of glycerin had lower viability than control parameters.

\section{Conclusion}

During storage of seeds of Nepeta cataria a gradual decrease in seed rate and energy of germination are noted. A year later, seed rate decreased by $20.25 \%$, after 2 years by $31.45 \%$, after 30 months by $34.55 \%$.

Freezing of Nepeta cataria's seeds in liquid nitrogen made it possible to maintain the viability of the seed material. The best container for freezing is plastic cryotubes. The best survival results of Nepeta cataria's seeds are noted with slow defrosting at room temperature $\left(20-24^{\circ} \mathrm{C}\right)$. The best option is freezing the seed material of Nepeta cataria at $3 \%$ moisture. The use of separate cryoprotectants made it possible to increase the results of seed rate and energy of germination of Nepeta cataria. The best results are obtained in variant of application glucose; the optimal concentration was $15 \%$.

Results of research are used for creation of a seed bank of medicinal plants.

This research is funded by the Science Committee of the Ministry of Education and Science of the Republic of Kazakhstan (Grant No. AP09259548 "Cryopreservation of wild and medicinal plant seeds and organization of a short-term and long-term storage bank").

\section{References}

1 Фармацевтический рынок Казахстана: история, основные направления развития и современное состояние. - Алматы: AEQUITA, 2015. - $36 \mathrm{c}$.

2 Грудзинская Л.М. Аннотированный список лекарственных растений Казахстана: справ. изд. / Л.М. Грудзинская, Н.Г. Гемеджиева, Н.В. Нелина, Ж.Ж. Каржаубекова. - Алматы, 2014. — 200 с.

3 Medical plant conservation. - Vol. 14. - Ontario, 2011. - $36 \mathrm{p}$.

4 Нестерова С.В. Криоконсервация семян дикорастущих растений Приморского края: дис. ... канд. биол. наук / С.В. Нестерова. - Владивосток, 2004. - 150 с.

5 Dixit S. Cryopreservation: a potential tool for long-term conservation of medicinal plants / S. Dixit, S. Ahuja, A. Narula, P.S. Srivastava // Plant Biotechnology and Molecular Markers. — New-Delhi: Anamaya Publisher, 2004. — P. $278-288$.

6 Chen S.-L. Conservation and sustainable use of medicinal plants: problems, progress and prospects / S. -L. Chen, H.-M. Luo, Q. Wu, C.-F. Li, A. Steinmetz // Chinese Medicine. - 2016. — Vol. 11 (37). - P. 2-10. DOI 10.1186/s13020-016-0108-7

7 Ishmuratova M.Yu. Cryopreservation of Calendula officinalis seeds / M.Yu. Ishmuratova, S.U. Tleukenova, S.N. Atikeyeva, A.K. Auelbekova, G.O. Zhezbayeva, Z.Z. Zhumagaliyeva // EurAsian Journal of BioScience. — 2020. — Vol. 14. — P. 501-505.

8 Al-Baba H. Cryopreservation and genetic stability assessment of threatened medicinal plant (Ziziphora tenuior L.) growth wild in Jordan / H. Al-Baba, R.A. Shilbi, M. Akash, T.A. Al-Qudah, R.W. Tahtamouni, H. Al-Ruwaieri // Jordan Journal of Biological Science. - 2015. - Vol. 8, No. 4. - P. 247-256.

9 Палий А.Е. Биологические активные вещества Nepeta cataria L. / А.Е. Палий, И.Н. Палий, Н.В. Марко, В.Д. Работягов // Бюл. Гл. Никит. бот. сада. — 2016. - Вып. 118. - С. 38-44.

10 Cigremis Y. In vitro antioxidant activity and phenolic composition of Nepeta cataria L. extracts / Y. Cigremis, Z. Ulukanlia, A. Ilcimb, M. Akgozc // International Journal of Agricultural Science and Technology. — 2013. — Vol. 1, No. 4. - P. 74-79.

11 Zomorodian K. Chemical composition and antimicrobial activities of essential oils from Nepeta cataria L. against common causes of oral infections / K. Zomorodian, M.J. Saharkhiz, S. Shariati, K. Pakshi, M.J. Rahimi, R. Khashei // Journal of Dentistry, Tehran University of Medical Sciences. — 2013. - Vol. 10, No. 4. - P. 329-337. 
12 Devyatov A. Study of Nerpetae catariae herba fruits as promising medicinal plant raw material / A.G. Devyatov, G.S. Lapshin, E.Yu. Babaeva, E.A. Motina, E.V. Zvezdina, V.V. Vandishev // Pharmacy \& Pharmocology. — 2019. — Vol. 7, Iss. 3. — P. $120-128$. DOI: $10.19163 / 2307-9266-2019-7-3-120-128$

13 Ashrafi B. Biological activity and chemical composition of the essential oil of Nepeta cataria L. / B. Ashrafi, P. Ranak, B. Ezatpour, G.R. Talei // Research in Pharmacy. — 2019. — Vol. 23, Iss. 2. - P. 336-343. DOI: 10.12991/jrp.2019.141

14 Sharma A. Pharmacology and toxicology of Nepeta cataria (Catmint) species of genus Nepeta: a review / A. Sharma, G.A. Nayik, D.S. Cannoo // Plant and Human Health. — 2019. — Vol. 3. — P. 285-299. DOI: 10.1007 / 978-3-030-04408-4_13

15 Adiguzel A. Antimicrobial and antioxidant activity of the essential oil and methanol extract of Nepeta cataria. / A. Adiguzel, H. Ozer, M. Sokmen, M. Gulluce, A. Sokmen, H. Kilic, F. Sahin, O. Baris // Pol. J. Microbiol. — 2009. — Vol. 58. — P. 69-76.

16 Morombaye S.M. Evaluation of the antimicrobial effect of Nepeta cataria and Basella alba against clinically resistant Acinetobacter baumannii in Nairobi, Kenya / S.M. Morombaye, M. Kangogo, G. Revathi, A. Nyerere, J. Ochora // Advances in Microbiology. — 2018. — № 8. - P. 790-803. DOI: 10.4236/aim.2018.810052

17 Compendium of Medicinal and Aromatic Plants. Volume II. Asia. — Triestre, 2006. — 295 p.

18 Флора Казахстана. — Т. 7. - Алма-Ата: Наука, 1964. - 345 с.

19 Sakai A. Development of cryopreservation techniques / A. Sakai // Cryopreservation of tropical plant germplasm. Current research progress and application. - Rome, 2000. - 215 p.

20 Кушнаренко С.В. Криосохранение апикальных меристем плодовых и ягодных культур: метод. реком. / С.В. Кушнаренко, И.Ю. Ковальчук, Н.В. Ромаданова. — Алматы, 2008. — 58 с.

21 Додонова А.Ш. Рекомендации по криоконсервации семенного материала лекарственных и эндемичных видов растений: справ. изд. / А.Ш. Додонова, Е.А. Гаврилькова, М.Ю. Ишмуратова, С.У. Тлеукенова. - Караганда: ТОО «Полиграфист», 2017. - $76 \mathrm{c}$.

22 Зорина М.С. Определение семенной продуктивности и качества семян интродуцентов / М.С. Зорина, С.П. Кабанов // Методики интродукционных исследований в Казахстане. — Алма-Ата: Наука, 1986. — С. 75-85.

\author{
М.Ю. Ишмуратова, Д.Ш. Байгараев, С.У. Тлеукенова, \\ Е.А. Гаврилькова, А.К. Рамазанов, А.Г. Жумина
}

\title{
Nepeta cataria тұқымдарының криоконсервациялау әдісін әзірлеу
}

\begin{abstract}
Мақалада Nepeta cataria медициналық өсімдігінің тұқымдарын криоконсервациялау нәтижелері берілген. Криоконсервация - өміршеңдігін жоғалтпай ұзақ уақыт сақтауды ұйымдастыруға мүмкіндік беретін тұқым материалдарын үнемдеудің перспективалық тәсілі. Мақаланың мақсаты Nepeta cataria тұқым материалдарын криоконсервациялау шарттарын оңтайландыру болып табылады. Қордағы тұқымдардың тірі қалуын бағалау тұқымдардың жылдамдығы мен сақтау кезінде өсу энергиясының сызықтық төмендеуін көрсетті. 30 айдан кейін $+5^{\circ} \mathrm{C}$ температурада қағаз орамында өсу 12,2 \%-ға дейін азайды; 4 жылдан кейін тұқым өміршеңдігін жоғалтты. Зерттеу жүргізу кезінде контейнердің түрі, еру жағдайы, тұқымның оңтайлы ылғалдылығы және криопротекторлар оңтайландырылды. Нәтижелер сұйық азоттағы криоконсервациялау үшін оңтайлы контейнер пластикалық криогендік түтіктер болғанын көрсетті; еріту - бөлме температурасында жүргізілді. Тұқымның ең жақсы жылдамдық ылғалдылығы 3 \%; ең үздік криопротектор 15 \% концентрациядағы глюкоза болды. Зерттеу нәтижелері Nepeta cataria тұқымдарын сұйық азотта ұзақ уақыт сақтауды ұйымдастыру үшін пайдаланылды (дәрілік өсімдіктер тұқымдарының криобанкі).
\end{abstract}

Кiлm сөздер: Nepeta cataria, дәрілік өсімдік, тұқымдық материалдар, өсімдік, сұйық азот, криоконсервация.

\author{
М.Ю. Ишмуратова, Д.Ш. Байгараев, С.У. Тлеукенова, \\ Е.А. Гаврилькова, А.К. Рамазанов, А.Г. Жумина
}

\section{Разработка методов криоконсервации семян Nepeta cataria}

В статье представлены результаты криоконсервации семян лекарственного растения Nepeta cataria. Криоконсервация - высокоперспективный метод для сохранения семенного материала, который позволяет организовать длительное хранение без потери жизнеспособности. Цель настоящего исследования - оптимизировать условия криоконсервации семенного материала Nepeta cataria. Оценка семенной всхожести в процессе хранения показала линейное снижение жизнеспособности в процессе хранения. После 30 месяцев при температуре $+5{ }^{\circ} \mathrm{C}$ в бумажной таре всхожесть снизилась до $12,2 \%$; после 4-х лет хранения семена потеряли всхожесть. При проведении исследования были оптимизированы тип тары, условия размораживания, оптимальная влажность и криопротекторы. Результаты показали, что оптимальным контейнером для криоконсервации в жидком азоте являлись пластиковые криопробирки; 
размораживание производилось при комнатной температуре. Лучшие показатели семенной всхожести получены при влажности $3 \%$; лучший криопротектор - глюкоза в концентрации $15 \%$. Результаты исследований использованы для организации длительного хранения семян Nepeta cataria в жидком азоте (семенной криобанк лекарственных растений).

Ключевые слова: Nepeta cataria, лекарственное растение, семенной материал, всхожесть, жидкий азот, криопротекторы, криоконсервация.

\section{References}

1 Farmatsevticheskii rynok Kazakhstana: istoriia, osnovnye napravleniia razvitiia i sovremennoe sostoianie [Pharmaceutical Market of Kazakhstan: history, general directions of development and current state]. (2015). Almaty: AEQUITA [in Russian].

2 Grudzinskaya, L.N., Gemedzhieva, N.G., Nelina, N.V., \& Karzhaubekova, Zh.Zh. (2014). Annotirovannyi spisok lekarstvennykh rastenii Kazakhstana [Annotated list of medicinal plants of Kazakhstan]. Almaty [in Russian].

3 Medical plant conservation (2011). Ontario, 14; 36.

4 Nesterova, S.V. (2004). Kriokonservatsiia semian dikorastushchikh rastenii Primorskogo kraia [Cryopreservation of wild plants of Primorsky Territory]. PhD thesis. Vladivostok [in Russian].

5 Dixit, S., Ahuja, S., Narula, A., \& Srivastava, P.S. (2004). Cryopreservation: a potential tool for long-term conservation of medicinal plants. Plant Biotechnology and Molecular Markers, New-Delhi: Anamaya Publisher.

6 Chen S.-L., Luo, H.-M., Wu, Q., Li, C.-F., \& Steinmetz, A. (2016). Conservation and sustainable use of medicinal plants: problems, progress and prospects. Chinese Medicine, 11 (37); 2-10. DOI 10.1186/s13020-016-0108-7

7 Ishmuratova, M.Yu., Tleukenova, S.U., Atikeyeva, S.N., Auelbekova, A.K., Zhezbayeva, G.O., \& Zhumagaliyeva, Z.Z. (2020). Cryopreservation of Calendula officinalis seeds. EurAsian Journal of BioScience, 14; 501-505.

8 Al-Baba, H., Shilbi, R.A., Akash, M., Al-Qudah, T.A., Tahtamouni, R.W., \& Al-Ruwaieri, H. (2015). Cryopreservation and genetic stability assessment of threatened medicinal plant (Ziziphora tenuior L.) growth wild in Jordan. Jordan Journal of Biological Science, 8 (4); 247-256.

9 Palij, A.E., Palij, I.N., Marko, N.V., \& Rabotyagov, V.D. (2016). Biologicheskie aktivnye veshchestva Nepeta cataria L. [Biological active compounds of Nepeta cataria L.]. Biulleten Glavnogo Nikitskogo botanicheskogo sada - Bulletin of the Main Nikitskii Botanical Garden, 118; 38-44 [in Russian].

10 Cigremis, Y., Ulukanlia, Z., Ilcimb, A., \& Akgozc, M. (2013). In vitro antioxidant activity and phenolic composition of Nepeta cataria L. extracts. International Journal of Agricultural Science and Technology, 1, 4; 74-79.

11 Zomorodian, K., Saharkhiz, M.J., Shariati, S., Pakshi, K., Rahimi, M.J., \& Khashei, R. (2013). Chemical composition and antimicrobial activities of essential oils from Nepeta cataria L. against common causes of oral infections. Journal of Dentistry, Tehran University of Medical Sciences, 10, 4; 329-337.

12 Devyatov, A., Lapshin, G.S., Babaeva, E.Yu., Motina, E.A., Zvezdina, E.V., \& Vandishev, V.V. (2019). Study of Nerpetae catariae herba fruits as promising medicinal plant raw material. Pharmacy \& Pharmocology, 7, 3; 120-128. DOI: 10.19163/23079266-2019-7-3-120-128

13 Ashrafi, B., Ranak, P., Ezatpour, B., \& Talei, G.R. (2019). Biological activity and chemical composition of the essential oil of Nepeta cataria L. Research in Pharmacy, 23, 2; 336-343. DOI: 10.12991/jrp.2019.141

14 Sharma, A., Nayik, G.A., \& Cannoo, D.S. (2019). Pharmacology and toxicology of Nepeta cataria (Catmint) species of genus Nepeta: a review. Plant and Human Health, 3; 285-299. DOI: 10.1007 / 978-3-030-04408-4_13

15 Adiguzel, A., Ozer, H., Sokmen, V., Gulluce, M., Sokmen, A., Kilic, H., Sahin, F., \& Baris, O. (2009). Antimicrobial and antioxidant activity of the essential oil and methanol extract of Nepeta cataria. Pol. J. Microbiol., 58; 69-76.

16 Morombaye, S.M., Kangogo, M., Revathi, G., Nyerere, A., \& Ochora, J. (2018). Evaluation of the antimicrobial effect of Nepeta cataria and Basella alba against clinically resistant Acinetobacter baumannii in Nairobi, Kenya. Advances in Microbiology, 8; 790-803. DOI: 10.4236/aim.2018.810052

17 Compendium of Medicinal and Aromatic Plants. (2005), II. Asia. Triestre.

18 Flora Kazakhstana [Flora of Kazakhstan] (1964). Vol. 7. Alma-Ata: Nauka [in Russian].

19 Sakai, A. (2000). Development of cryopreservation techniques. Cryopreservation of tropical plant germplasm. Current research progress and application. Rome.

20 Kushnarenko, S.V., Kovalchuk, I.Yu., \& Romadanova, N.V. (2008). Kriosokhranenie apikalnykh meristem plodovykh i yagodnykh kultur [Cryopreservation of apical meristems of fruit and berry cultures]. Almaty [in Russian].

21 Dodonova, A.Sh., Gavrilkova, E.A., Ishmuratova, M.Yu., \& Tleukenova, S.U. (2017). Rekomendatsii po kriokonservatsii semennogo materiala lekarstvennykh i endemichnykh vidov rastenii [Recommendations for cryopreservation of seed material of medicinal and endemic plant species]. Karaganda: TOO "Poligrafist" [in Russian].

22 Zorina, M.S., \& Kabanov, S.P. (1986). Opredelenie semennoi produktivnosti i kachestva semian introdutsentov [Determination of seed productivity and quality of seeds of introduced plants]. Metodiki introduktsionnykh issledovanii v Kazakhstane - Methodology of introduction research in Kazakhstan. Alma-Ata: Nauka [in Russian]. 